\title{
EFFECT OF FEEDING REGIME AND SEX ON GROWTH PERFORMANCE AND FEED UTILIZATION OF POST LARVAL FRESH WATER PRAWN Macrobrachium rosenbergii (de Man 1879) \\ Kabir Chowdhury, M. A. ${ }^{1}$; E. R. El-Haroun ${ }^{1,3^{*}}$; A. M. Goda ${ }^{2}$; M. A. Wafa ${ }^{2}$ and S. A. Salah EI-Din ${ }^{2}$ \\ ${ }^{1}$ Fish Nutrition Research Laboratory, Animal and Poultry Science, Ontario, Agriculture College, Guelph University, Guelph, Ontario, Canada. \\ ${ }^{2}$ Fish Nutrition Research Laboratory, National Institute of Oceanography and Fisheries, Cairo, Egypt (NIOF). \\ ${ }^{3}$ Fish Nutrition Research Laboratory, Animal Production Department, Faculty of Agriculture, Cairo University, Cairo, Egypt \\ ${ }^{*}$ Correspondence author: Fish Nutrition Research Laboratory, Animal Production Department, Faculty of Agriculture, Cairo University, Giza, Egypt. elharoun@uoguelph.ca
}

\begin{abstract}
The aim of this study was to investigate the effect of feeding regime protein level and feeding time and sex on growth performance, feed utilization, survival rate and body composition of post larvae of freshwater prawn Macrobrachium rosenbergii. Post-larvae (PL) of $M$. rosenbergii, 30 day-old with an average weight of $20.8 \pm 0.17$ $\mathrm{mg}$ were fed at two different dietary protein $35 \%$ and $40 \% \mathrm{CP}$ and isocaloric diets 360 kcal DE $100 \mathrm{~g}^{-1}$. The ration was fed twice a day at three different feeding times (9:00; $12: 00 \mathrm{~h}) ;(9: 00 ; 15: 00 \mathrm{~h})$ and $(9: 00 ; 18: 00 \mathrm{~h})$. The experiment was conducted in concrete tanks $\left(6 \mathrm{~m}^{-3}\right)$ for 84 days at a stocking density of $30 \mathrm{PL} \mathrm{m}^{-3}$. The daily feed ration was fed of their collective body weight at feeding rate of $10 \%$ from 0.2 to $1.0 \mathrm{~g}$ prawn, $7 \%$ for $1-5 \mathrm{~g}$ prawn and $5 \%$ for greater than $5 \mathrm{~g}$ prawn. The higher significant values $(P \leq 0.05)$ of survival rate, weight gain and specific growth rate $(P \leq 0.05)$ were observed for prawn fed diet at $35 \% \mathrm{CP}$. The same trend was observed for prawn PL fed with feeding time (9:00: 15:00 h). The prawn PL either fed at 35\% protein diet or feeding time (9:00: 18:00 h) showed the better-feed conversion ratio $(P \leq 0.05)$. The highest protein efficiency ratio, fat retention and energy retention $(P \leq 0.05)$ were showed for prawn PL fed diet at 35\% CP with feeding time (9:00;18:00 h). No significant difference was observed for the effect of dietary protein on whole body dry matter and protein contents. However, prawn carcass gained more fat $(P \leq 0.05)$ when fed diet at 35\% CP. Meanwhile, prawn fed at (9:00: 15:00 h) showed the highest carcass crude protein and lowest fat and ash contents $(P \leq 0.05)$. Generally, males of $M$. rosenbergii recorded the better growth performance and feed utilization than the females either at different dietary protein levels or different feeding time. The results of the present study revealed that prawn $M$. rosenbergii PL fed diet at either $35 \% \mathrm{CP}$ or feeding time $(9: 00 ; 15: 00 \mathrm{~h})$ obtain an optimum growth performance and feed utilization.
\end{abstract}

Keywords: Protein level, feeding time, freshwater prawn, post larvae, growth.

\section{INTRODUCTION}

World production of freshwater prawn increased from $<50,000$ MT (metric tons) in 1995 to > 280,000 MT in 2003 (New 2005; FAO 2005) and has become an important part of the rice-fish or small scale carp polyculture 
ecosystem in developing countries, such as Vietnam (Giap et al., 2005) and Bangladesh (Hossain and Islam 2006). Algal culture and nutritional enrichment of algae as larval food for prawn and other fish species has shown tremendous potential in successful rearing of aquaculture species (Chowdhury et al., unpublished data). The effect of dietary protein levels on post-larval $M$. rosenbergii has also been investigated in the past few decades (Balazs and Ross 1976; Ashmore et al., 1985; D'Abramo and Sheen 1994; Sharma and Reddy 1996; El-Sayed 1997). However, recent findings of lower protein requirement of the freshwater prawn $M$. rosenbergii showed that nitrogen $(\mathrm{N})$ needed for their maintenance was lower than that needed for the marine prawn M. japonicus (Teshima et al., 2001; Teshima et al., 2006) and fish such as carp, Cyprinus carpio, and rainbow trout, Salmo gairdneri (Ogino et al., 1976; Ogino 1980).

The optimum dietary protein levels for prawn can change depending on feeding level, feeding frequency, feeding time, sex and other factors such as protein quality, and diet composition (Teshima et al., 2001). Meyers (1987) reported that understanding feeding behavior of cultured species can assist in the development of feeds and regimes that reduce the metabolic energy costs in feeding and encourage consumption. However, in the case of crustaceans, it is generally difficult to measure appropriate feed intake in feeding experiments because of the slow feeding habit of these organisms resulting in the leaching of some nutrients. Teshima and Kanazawa (1987) reported that for the prawn $M$. rosenbergii about $36-40 \%$ of given diets was found to be lost to the water and not ingested, as pointed out in tracer experiments on the marine prawn $M$. japonicus.

There is limited research on evaluation of diets for indoor or outdoor nursery rearing of post-larvae of $M$. rosenbergii (Briggs et al., 1988; Heinen and Mensi 1991). Most of the studies have been carried out on nutritional requirements of sub-adults and adults (Gitte and Indulkar 2005). However, information is needed for production of juveniles by minimizing nursery costs, as the cost of producing nursed juveniles has emerged as a major factor influencing the profitability of the nursery operators and prawn farmers. Therefore, in the present study, an attempt was made to evaluate the effect of dietary protein levels and different feeding times on growth performance and feed utilization of freshwater prawns Macrobrachium rosenbergii post larvae.

\section{MATERIALS AND METHODS}

\section{Experimental design and culture techniques}

A grow-out experiment of freshwater prawn $M$. rosenbergii post larvae (PL) was conducted at the Fish Farm Research Station of the National Institute of Oceanography and Fisheries (NIOF), Cairo, Egypt for 84 days. The freshwater prawns were obtained from Saft-Khalid hatchery, General Authority for Fish Resources Development, El-Bhira Governorate, Egypt. The prawns were acclimated for two weeks in one concrete pond $(8 \times 4 \times 1 \mathrm{~m})$. At the end of the acclimation period, post-larvae of $M$. rosenbergii (30 day-old with an average weight of $20.8 \pm 0.17 \mathrm{mg}$ ) were stocked into two cement ponds of $40 \mathrm{~m}^{-3}$ each, where a two $\mathrm{cm}$ thick layer of clean, fine sand was 
spread evenly on the bottom of each ponds. Each cement pond was divided into nine equal pens by nets $\left(6 \mathrm{~m}^{-3}\right)$. Experiments were carried out in triplicates for each treatment with stocking density of $30 \mathrm{PL} \mathrm{m}^{-3}$. Each culture pen was provided four $30 \mathrm{~cm}$ long $16 \mathrm{~mm}$ diameter black polyvinyl chloride (PVC) pipe to minimize the cannibalism during the molting as suggested by Mariappan and Balasundaram (2004). During the acclimation, prawn larvae were fed on commercial tilapia diet $(30 \% \mathrm{CP})$. The pond was supplied with fresh water from the Darawa Irrigation Branch, Kalubiya Governorate. The turnover rate of water was $25 \%$ day $^{-1}$ pond $^{-1}$.

At the beginning of the experiment, three healthy groups of 40 prawns were randomly sampled, weighed, immediately killed and frozen at $20 \stackrel{\circ}{ } \mathrm{C}$ for initial carcass analysis. In addition, at the end of the experiments, 10 prawns were obtained from each treatment for the carcass composition. Another five males and five females were obtained from each treatment for the final carcass analysis.

\section{Experimental diets}

Two isocaloric ( 360 kcal DE $100 \mathrm{~g} \mathrm{~g}^{-1}$ ) diets of $35 \%$ and $40 \%$ crude proteins were formulated (Table 1 ). The diets were processed by blending the dry ingredients into a homogenous mixture, and then the mixture was passed through laboratory pellet mill in the National Institute of Oceanography and Fisheries, Cairo, Egypt (a California Pellet Mill Co., San Francisco, California). PL were fed of their collective body weight at feeding rate of $10 \%$ from 0.2 to $1.0 \mathrm{~g}$ prawn, $7 \%$ for $1-5 \mathrm{~g}$ prawn and $5 \%$ for greater than $5 \mathrm{~g}$ prawn according to Poadas ( 2004). The daily ration was provided twice a day in equal amount at three different feeding times (9:00: 12:00 h); (9:00: 15:00 h) and (9:00: 18:00 h). The feed ingredients fish meal, poultry byproduct, soybean meal, yellow corn, wheat bran, vitamins and minerals premix were purchased from the Animal Production Islamic company (APICO), 24 Gaber ben Haian St., Dokki- El- Giza, Egypt. Soybean oil was purchased from local market.

\section{Growth parameters}

Initial and final weight of individual prawns was recorded by an electronic balance $( \pm 0.001 \mathrm{~g})$. In addition, during each sampling, ten males and ten females from each treatment were randomly selected and weighed thereafter. The first sampling was conducted on the $30^{\text {th }}$ day after stocking and at 15 days interval thereafter. The quantity of daily diet was adjusted after each sampling. Weight gain (WG), specific growth rate (SGR), feed conversion ratio ( $F C R$ ), protein efficiency ratio (PER), protein productive value (PPV), fat retention (FR) and energy retention (ER) were calculated using the following equations:

$W G=$ Final body weight $(\mathrm{g})$ - Initial body weight $(\mathrm{g})$

$\mathrm{SGR}=[($ In FBW - In IBW $) \times 100] /$ day, where: FBW is final body weight $(\mathrm{g})$;

IBW is initial body weight $(\mathrm{g})$; and $\mathrm{In}=$ natural logarithmic

$\mathrm{FCR}=$ Feed intake $(\mathrm{g}) /$ weight gain $(\mathrm{g})$

$\mathrm{PER}=$ Weight gain $(\mathrm{g}) /$ protein intake $(\mathrm{g})$.

PPV $=($ Retained protein $(\mathrm{g}) /$ protein intake $(\mathrm{g})) \times 100$

$\mathrm{FR}=($ Retained fat $(\mathrm{g}) /$ fat intake $(\mathrm{g})) \times 100$

$\mathrm{ER}=($ Retained energy $(\mathrm{kcal}) /$ energy intake $(\mathrm{kcal})) \times 100$ 
Kabir Chowdhury, M. A. et al.

Table 1: Chemical composition and proximate analysis of the experimental diets (\% dry matter).

\begin{tabular}{|c|c|c|}
\hline \multirow[t]{2}{*}{ Ingredients } & \multicolumn{2}{|c|}{ Experimental treatment } \\
\hline & $35 \%$ & $40 \%$ \\
\hline Fish meal & 10 & 10 \\
\hline Poultry by-product meal & 28 & 33 \\
\hline Soybean meal & 23 & 28 \\
\hline Wheat bran & 16 & 14 \\
\hline Yellow corn & 13 & 9 \\
\hline Corn oil & 8 & 4 \\
\hline \multirow{2}{*}{\multicolumn{3}{|c|}{ Proximate composition }} \\
\hline & & \\
\hline Dry matter, \% & 91.12 & 90.94 \\
\hline Crude protein, \% & 35.39 & 39.26 \\
\hline Lipi & 11.60 & 10.41 \\
\hline Total carbohydrate, \% & 39.41 & 35.11 \\
\hline Ash, \% & 13.60 & 15.22 \\
\hline Gross energy ${ }^{2}, \mathrm{kcal} 100 \mathrm{~g}^{-1}$ & 471.15 & 464.14 \\
\hline Digestible energy ${ }^{3}, \mathrm{kcal}^{100 \mathrm{~g}^{-1}}$ & 360.17 & 360.21 \\
\hline Protein: energy ratio, $\mathrm{mg} \mathrm{kcal}^{-1}$ & 98.26 & 109.00 \\
\hline \multicolumn{3}{|c|}{ 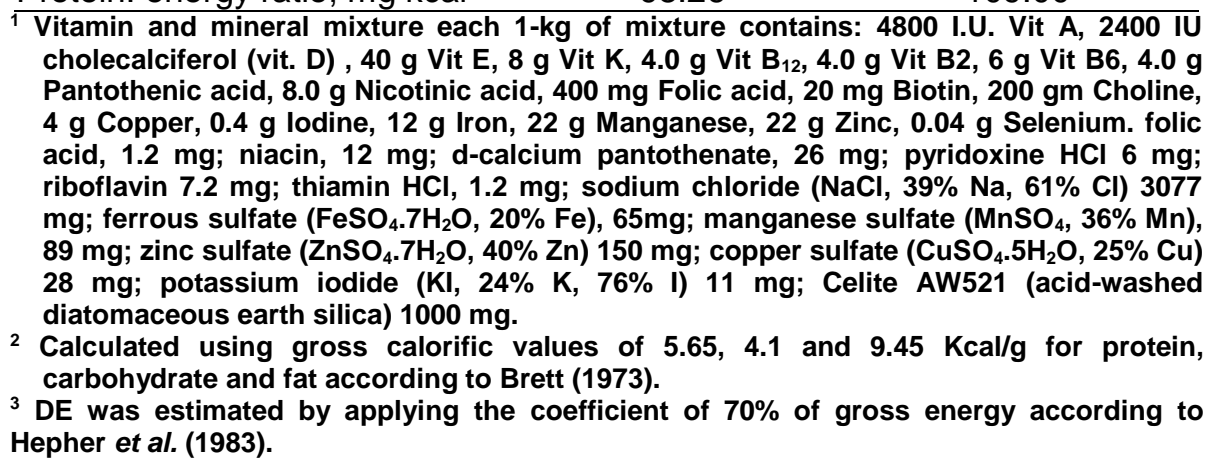 } \\
\hline
\end{tabular}

\section{Proximate analysis}

The proximate analysis of diet, ingredients and whole body composition were determined following AOAC (1995). Gross energy content of diet and whole body samples was calculated according to the gross caloric values by applying the factor $5.65 \mathrm{kcal} \mathrm{g}^{-1}, 9.45 \mathrm{kcal} \mathrm{g}^{-1}$, and $4.1 \mathrm{kcal} \mathrm{g}^{-1}$ of crude protein, crude fat and total carbohydrate respectively. Dietary digestible energy (DE) was estimated using values of $5.0,9.0$ and $4.0 \mathrm{kcal} \mathrm{g}^{-1}$ for crude protein, ether extract and carbohydrate, respectively according to Das et al. (1996).

\section{Statistical analysis}

The data were analyzed using the MSTATE program software ANOVA procedure (MSTATE 1987) in a factorial design manner $(2 \times 3)$. Duncan's multiple range test (Duncan 1955) was used when ANOVA F values were significant to compare differences among individual means. Treatment effects were considered significant at $(P \leq 0.05)$. 


\section{RESULTS}

The growth performance of fresh water prawn Macrobrachium rosenbergii in terms of final body weight (FBW), weight gain (WG), specific growth rate (SGR) and feed utilization in terms of FCR, PER, PPV, FR, and ER are shown in Table 2. The highest FBW (7.25g), WG (7.23g) and SGR $\left(6.97 \%\right.$ day $\left.^{-1}\right)$ were observed for prawn fed diet at $35 \%$ CP $(P \leq 0.05)$. The same trend was observed for PL fed diet at feeding time $(9.00: 15.00 \mathrm{~h})$, while; the lowest value was recorded at feeding time $(9.00: 18.00 \mathrm{~h})$. The prawn fed $35 \%$ CP diet or at feeding time (9.00: $18.00 \mathrm{~h}$ ) showed significantly better FCR (2.21 and 2.37, respectively), while the worst value (2.63) was recorded for $\mathrm{PL}$ fed diet containing $40 \% \mathrm{CP}$. The highest protein efficiency ratio (1.40), protein productive value $(19.09 \%)$, fat retention $(25.03 \%)$ and energy retention (18.56\%) were recorded for the PL fed $35 \%$ CP diet. The same trend was observed for protein efficiency ratio (1.24\%), fat retention $(23.57 \%)$ and energy retention (13.01\%) for PL fed with (9:00: 18:00 h) feeding time. Irrespective of dietary protein levels or feeding times, males of $M$. rosenbergii recorded the better growth performance and feed utilization than the females in all scenarios Table 3 . The same trend was observed for FCR and PER. The highest survival rate was observed for M.rosenbergii PL fed diet at $35 \%$ CP $(76 \%)$ and at $9.00,15.00$ h feeding time $(71.5 \%)$.

Table 2: Effect of different dietary protein levels and feeding time irrespective of each other on growth performance and feed utilization of freshwater prawn Macrobrachium rosenbergii post larvae.

\begin{tabular}{|c|c|c|c|c|c|c|c|}
\hline Parameters & $35 \% \mathrm{CP}$ & $40 \% \mathrm{CP}$ & MSE \pm & 9: $12 \mathrm{~h}$ & 9: $15 \mathrm{~h}$ & 9: $18 \mathrm{~h}$ & MSE \pm \\
\hline Initial body weight, g prawn ${ }^{-1}$ & 0.0208 & 0.0208 & 0.17 & 0.0208 & 0.0208 & 0.0208 & 0.017 \\
\hline Final body weight, g prawn ${ }^{-1}$ & $7.25^{a}$ & $6.70^{\mathrm{b}}$ & 0.45 & $7.08^{a b}$ & $7.19^{a}$ & $6.67^{\mathrm{c}}$ & 0.56 \\
\hline Survival rate $(\%)$ & $76.00^{a}$ & $72.50^{b}$ & 0.50 & $68.50^{b}$ & $71.50^{a}$ & $70.00^{a b}$ & 0.75 \\
\hline Weight gain g 84 days $^{-1}$ prawn $^{-1}$ & $7.23^{a}$ & $6.68^{b}$ & 0.65 & $7.06^{\mathrm{ab}}$ & $7.17^{a}$ & $6.65^{c}$ & 0.12 \\
\hline Specific growth rate( $\%$ day) & $6.97^{a}$ & $6.88^{b}$ & 0.55 & $6.94^{\mathrm{ab}}$ & $6.96^{\mathrm{a}}$ & $6.87^{b}$ & 0.18 \\
\hline Feed conversion ratio & $2.21^{\mathrm{b}}$ & $2.63^{a}$ & 0.54 & $2.43^{a}$ & $2.44^{\mathrm{a}}$ & $2.37^{b}$ & 0.2 \\
\hline Protein efficiency ratio & $1.40^{\mathrm{a}}$ & $1.18^{\mathrm{b}}$ & 0.30 & $1.22^{a b}$ & $1.20^{\mathrm{b}}$ & $1.24^{\mathrm{a}}$ & 0.01 \\
\hline Protein productive value & $19.09^{a}$ & $15.81^{b}$ & 2.66 & $14.46^{c}$ & $18.12^{a}$ & $17.07^{\mathrm{ab}}$ & 1.12 \\
\hline Fat retention & $25.03^{a}$ & $18.56^{b}$ & 2.66 & $22.26^{\mathrm{ab}}$ & $19.28^{c}$ & $23.57^{a}$ & 2.32 \\
\hline Energy retention & $18.56^{a}$ & $10.78^{\mathrm{b}}$ & 1.25 & $11.73^{b}$ & $12.23^{a b}$ & $13.01^{a}$ & 1.36 \\
\hline
\end{tabular}

Means in the same row sharing the same superscript are not significantly different $(P \geq 0.05)$.

Proximate body compositions of $\mathrm{M}$. rosenbergii $\mathrm{PL}$ are presented in Table 4. No significant difference $(P \geq 0.05)$ was observed in the whole body dry matter (DM) and protein contents between the dietary protein treatments. However, higher body fat content $(23.85 \%)$ and gross energy $\left(5.39 \mathrm{kcal} \mathrm{g}^{-1}\right)$ were observed when fed 35\% CP diet. Meanwhile, prawn fed at (9:00:15:00 h) showed the highest whole body protein $(62.29 \%)$ and the lowest fat contents (18.46\%) and ash content (19.25\%).

$\mathrm{PL}$ female fed $35 \% \mathrm{CP}$ diet recorded the highest values for whole body fat $(27.07 \%)$, while the PL male fed $40 \%$ CP diet showed the lowest significant $(P<0.05)$ values of whole body fat content $(18.55 \%)(P<0.05$; Table $5)$. The same trend was observed for the whole body gross energy (5.72 and $4.86 \mathrm{kcal} \mathrm{g}^{-1}$ respectively). However, the highest significant protein content $(63.17 \%)$ of the whole body male was observed at feeding time (9:00: 15:00 h) that associated with the lower whole body fat content (15.53\%). 
Kabir Chowdhury, M. A. et al. 


\section{DISCUSSION}

The present study showed that $35 \%$ protein diet was optimal to achieve the maximum growth performance in $M$. rosenbergii PL. Balazs and Ross (1976) estimated dietary protein requirement at three levels of protein $(15 \%, 25 \%$ and $35 \%$ protein diet) and reported that a dietary protein concentration of $35 \%$ was required to attain the maximum growth rate for juvenile $M$. rosenbergii. Andrews et al. (1972) studied the effect of protein levels $(28 \%, 32 \%, 40 \%$ and $52 \%)$ in $P$. setiferus, and observed lower growth rate at $40 \%$ protein than at $28 \%$ and interestingly that a $52 \%$ protein diet resulted in further growth depression. Results of the present study are in agreement with the findings of Teshima et al. (2006) who reported that protein sparing effect of high protein diet $(>35 \% \mathrm{CP})$ shows an increase in fat content in $M$. rosenbergii compare to the prawns fed diets of $35 \%$ CP. This is indicative that the increase in dietary protein levels exceeding the minimum requirement results in the loss of expensive protein in $M$. rosenbergii diets and accumulation of fats. Nevertheless, the protein requirement of the freshwater prawn $M$. rosenbergii $\mathrm{PL}$ is considered to be lower than other prawn species and this may be due to less protein requirement for maintenance compared to carnivorous marine prawn species (Balazs and Ross 1976; Koshio et al., 1992; D'Abramo and Sheen 1994).

Higher growth performance of male prawn was observed in all treatments irrespective of crude protein content and feeding time. This is similar to those of Nair et al. (2006). Higher FCRs registered at $40 \% \mathrm{CP}$ treatments indicate that protein was used as energy when the supply exceeded the requirement for growth. Moreover, the feed conversion ratio $(2.21-2.63)$ and protein efficiency ratio $(1.18-1.40)$ obtained in the present study were lower than those observed by Ashmore et al (1985) and Hari and Kurup (2002). Higher FCR was observed by Cortes-Jacinto et al. (2003) for juvenile freshwater crayfish fed high protein diets. The mean values of feed conversion ratio of the present study were better than those obtained in the previous feeding trials and in agreement with the values obtained by Balazs and Ross (1976) when M. rosenbergii was reared in outdoor tanks fed with various combinations of protein sources (FCR ranged from 1.62 to 2.20). This difference can be attributed to the substantial contribution of certain type of algae present in outdoor pond to the experimental animal's nutrition (Balazs and Ross, 1976). In the pond culture study, natural food items in the pond may have satisfied a part of the protein requirement of omnivorous $M$. rosenbergii PL. Consequently, this may explain why pond-cultured $M$. rosenbergii can be fed a plant based low protein diet compared to the $M$. rosenbergii grown indoors. However, it is difficult to quantify the contribution of natural foods to the diet of prawn, as this is beyond the scope of the study.

In the present study, $M$. rosenbergii PL fed diet at feeding time $(9.00: 15.00 \mathrm{~h})$ showed the best $(P \leq 0.05)$ growth performance compare to the $\mathrm{PL}$ fed at $(9.00: 12.00 \mathrm{~h})$ or $(9.00: 18.00 \mathrm{~h})$. The result agreed with the finding of Wilkinson (2003) who reported that the time of the day that feed is 
delivered associate with feeding organisms behavior that could be affect growth performance. Protein and energy retention seemed low compared to the findings in fishes e.g. rainbow trout (40-60\%; Cuzon et al., 2004). However, prawn like any crustacean release cast at each molt, which can represent an energetic expenditure of $26 \%$ of the overall inter-molt energy gain (Read and Caulton 1980). Cuzon et al. (2004) reported that protein requirement is probably not as highly correlated with protein accretion compared to vertebrates due to chitin synthesis; chitin is a polysaccharide containing nitrogen equivalent to $43 \%$ crude protein. The highest survival rates shown in the present study may be attributed to the fulfillment of dietary requirement (Das et al. 1996) and the PVC pipe that may have helped the prawn to overcome molting stress and to avoid cannibalism (Mariappan and Balasundaram 2004).

In conclusion, the present study revealed that prawn $M$. rosenbergii PL fed diet at either 35\% CP or feeding time (9:00: 15:00 h) shows optimum growth performance and feed utilization. Generally, the growth and feed utilization of male $M$. rosenbergii were the better than the female at different dietary protein levels or feeding times.

\section{ACKNOWLEDGEMENTS}

The authors extend their gratitude to Prof. Dr. Mamdouh T. Kheir for their technical assistance during the experiments. The author wish to thank the Prof. Dr. H. Soliuman of the National Institute of Oceanography and Fisheries, Cairo, Egypt (NIOF) and Professor A. Eizat for their technical support, valuable suggestions, and comments during the study.

\section{REFERENCES}

Andrews J.W.; L.V. Sick and J. Baptist (1972). The influence of dietary and energy levels on growth and survival of penaeid shrimp. Aquaculture 1, 431-347.

AOAC (Association of Official Analytical Chemists). (1995) Official methods of analysis, 16th edition. Association of Official of Analytical Chemists, Inc., Arlington, Virginia, USA.

Ashmore S.B.; R.W. Stanley; L.B. Moore and S.R. Malecha (1985) Effect on growth and apparent digestibility of diets varying in grain source and protein level in Macrobrachium rosenbergii. Journal of the World Mariculture Society 16, 205- 216.

Balazs G.H and E. Ross (1976) Effect of protein source and level on growth and performance of captive fresh water prawn, Macrobrachium rosenbergii. Aquaculture 7, 299-313.

Brett, J.R. (1973) Energy expenditure of Sockeye salmon Oncorhynchus nerka, during sustained performance. Journal of the fisheries research board of Canada, 30-1799-1801. 
Briggs M.R.P.; K. Jauncey and J.H Brown. (1988) The cholesterol and lecithin requirements of juvenile prawn (Macrobrachium rosenbergii) fed semi-purified diets. Aquaculture 70, 121-129.

Chowdhury M.A.K.; N.G. Das; E.R. El-Haroun and M.L. Bose. Salinity preference of two diatoms and their growth performance in three prepared and two alternative on-farm media sources. Applied Aquaculture (In press).

Cortes-Jacinto E.; H. Villarel-Colmenares; R. Civera-Cerecedo and R. Martinez-Cordova (2003) Effect of dietary protein level on growth and survival of juvenile freshwater crayfish Cheraxquadricarinatus (Decapoda: Parastacidae). Aquaculture Nutrition 9, 207-213.

Cuzon G.; A.L. Lawrence; G. Gaxiola; C. Rosas and J. Guillaume (2004) Nutrition of Litopenaeus vannamei reared in tanks or in ponds. Aquaculture 235, 513-551.

D'Abramo L.R. and S.S. Sheen (1994) Nutritional requirements, feed formulation, and feeding practices for intensive culture of the freshwater prawn Macrobrachium rosenbergii. Reviews in Fisheries Science 2, 1-21.

Das N.N.; C.R. Saad; K.J. Ang; A.T. Law and S.A. Harmin (1996) Diet formulation for Macrobrachium rosenbergii (de Man) brood-stock based on essential amino acid profile of its eggs. Aquaculture Research 27, $543-555$.

Duncan, D. B. (1955) Multiple range and $F$ tests. Biometrics 11, 1-42.

El-Sayed A.F.M. (1997) Growth rates and feed efficiency of the freshwater prawn Macrobrachium rosenbergii fed varying protein and energy levels. Bulletin of National Institute of Oceanography and Fisheries, Egypt 23, 539-448.

FAO (Food and Agricultural Organization) (2005) Fishery Statistics. Fisheries Global Aquaculture Production Database for freshwater crustaceans. at: http: www.faostat.fao.org /faostat. /notes/units-e.html.

Giap D.H.; Y. Yi and C.K. Lin (2005) Effect of different fertilization and feeding regimes on the production of integrated farming of rice and prawn Macrobrachium rosenbergii (De Man). Aquaculture Research 36, 292-299.

Gitte M.J. and S.T. Indulkar (2005) Evaluation of marine fish meat incorporated diets on growth and survival of post-larve of Macrobrachium rosenbergii (de Man). Asian Fisheries Science 18, 323334.

Hari B. and B.M. Kurup (2002) Vitamin C (Ascorbyl 2 Polyphosphate) Requirement of Freshwater Prawn Macrobrachium rosenbergii (de Man). Asian Fisheries Science 15, 145-154.

Heinen J.M. and M.J. Mensi (1991) Feed and feeding schedules for indoor nursery culture of post-larval freshwater prawns. Journal of the World Aquaculture Society 22, 118-127.

Hepher, B.; L.C.Liao; S.H.Shang and C.S.Haseih (1983).Food utilization by red tilapia. Effect of diet composition, feeding level, and temperature on utilization efficiency for maintenance and growth. Aquaculture, 32-255272. 
Kabir Chowdhury, M. A. et al.

Hossain M.A. and M.S. Islam (2006) Optimization of stocking density of freshwater prawn Macrobrachium rosenbergii (de man) in carp polyculture in Bangladesh. Aquaculture Research 37, 994-1000.

Koshio S.; A. Kanazawa and S. Teshima (1992) Search for effective protein combination with crab protein for the larval Kuruma prawn Penaeus japonicus. Nippon Suisan Gakkaishi 58, 1083-1089.

Mariappan M. and C. Balasundaram (2004) Sheltering behaviour of Macrobrachium nobilii (Henderson and Matthai, 1910). Acta Ethologica 5, 89-94.

Meyers S.P. (1987) Aquaculture feeds and chemoattractants. Infofish Marketing Digest, $1 / 87,35-37$.

MSTAT Version 4 (1987). Software program for the design and analysis of agronomic research experiments. Michigan St. Univ., M. S., U.S.A.

Nair C.M.; K.R. Salin; M.S. Raju and M. Sebastian (2006) Economic analysis of monosex culture of giant freshwater prawn (Macrobrachium rosenbergii De Man): a case study. Aquaculture Research 37, 949954.

New M.B. (2005) Freshwater prawn farming: global status, recent research and a glance at the future. Aquaculture Research 36, 210-230.

Poadas, B. C. (2004) Effects of two palletized feed formulations on experimental freshwater prawn, Macrobrachium rosenbergii, pond production, processing and costs. Journal Applied Aquaculture, 16 (3/4): 155-165.

Ogino C. (1980) Protein requirements of carp and rainbow trout. Bulletin of the Japanese Society of Scientific Fisheries 46, 385-388.

Ogino C.; J.Y. Chiou and T. Takeuchi (1976) Protein nutrition in fish. VI. Effects of dietary energy sources on the utilization of proteins by rainbow trout and carp. Bulletin of the Japanese Society of Scientific Fisheries 42, 213-218.

Read G.H.L. and M.S. Caulton (1980) Changes in mass and chemical composition during the molt cycle and ovarian development in immature and mature Penaeus indicus Milne Edwards (J). Comparative Biochemistry and Physiology 66, 431-437.

Sharma M. and A.K. Reddy (1996) Intensive culture of freshwater prawn Macrobrachium rosenbergii in cement tanks. Fisheries Chimes 16, 2526.

Teshima S.; S. Koshio; M. Ishikawa and A. Kanazawa (2001) Protein requirement of the prawn Marsupenaeus japonicus estimated by a factorial method. Hydrobiologia 449, 293-300.

Teshima S. and A. Kanazawa (1987) Turnover of dietary cholesterol and bsitosterol in the prawn. Nippon Suisan Gakkaishi 53, 601-607.

Teshima S., S. Koshio; M. Ishikawa; M.S. Alam and L.H.H. Hernandez (2006) Protein requirements of the freshwater prawn Macrobrachium rosenbergii evaluated by the factorial method. Journal of the World Aquaculture Society 37, 145-153.

Wilkinson S. (2003) Aquaculture Fundamentals: Getting the most out of your feed Aquaculture Asia 2003 (1): 50-53. 
تـأثير نظـام التظذيـة والجنس على معدلات النمـو والاسـتفادة مـن الغذاء ليرقـات جمبري المياة العذبة التئة

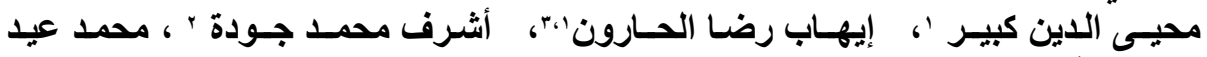

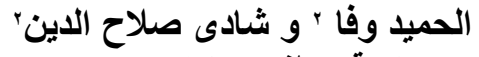

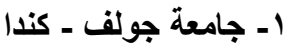

r- معمل أبحاث تغذية الأسماك ـ المعهل القومي لعلوم البحار والمصايد - وزارة البحث العلمي ـ

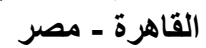

r- مععل أبحاث تغذية الأسماك ـ قسم الإتتاج الحيواني-كلية الزراعة - جامعة القاهرة-الجيزة ـ

أجريت هذه الدراسة بهدف دراسة تأثير نظام التغذية وبشمل (مستوى البروتين ووقت

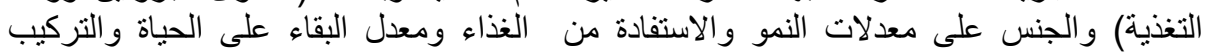

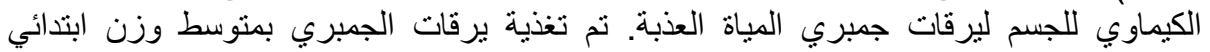

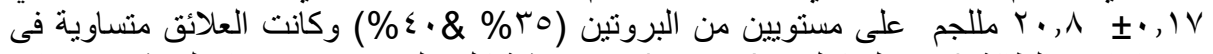

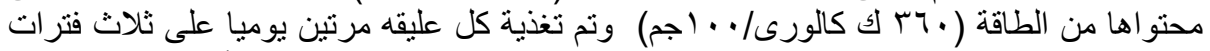

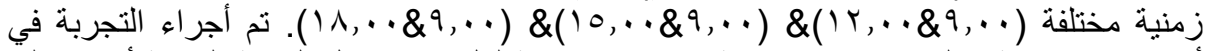

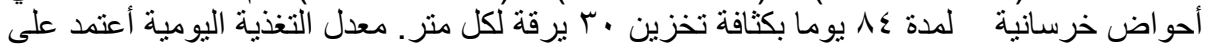

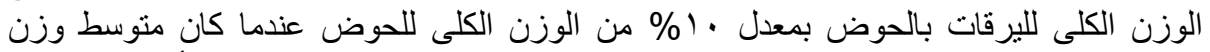

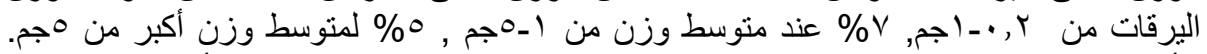

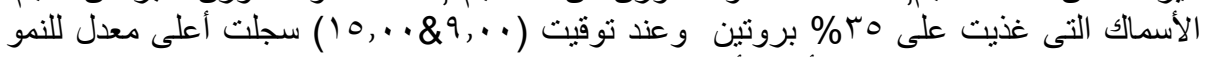

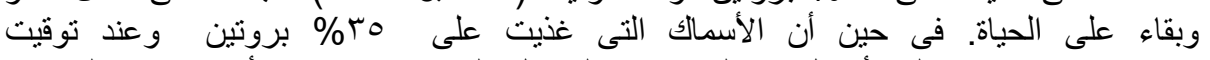

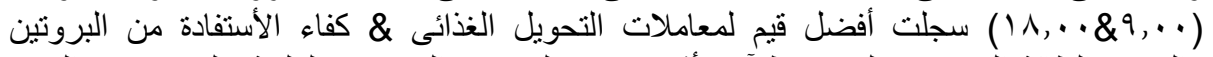

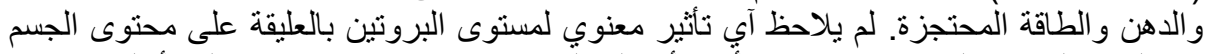

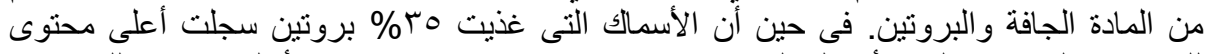

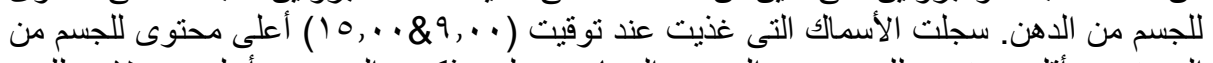

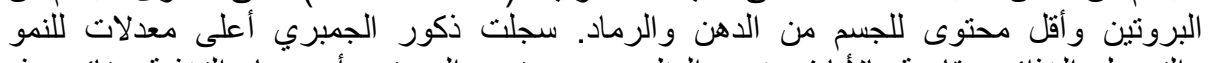

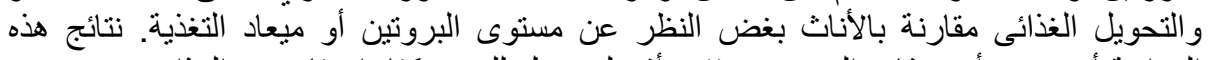

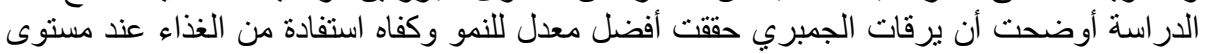

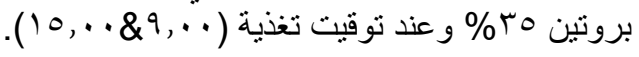



J. Agric. Sci. Mansoura Univ., 32 (6): 4321 - 4331, 2007 
Table 3: Effect of different dietary protein levels and feeding time irrespective of each other on growth performance and feed utilization of male and female freshwater prawn Macrobrachium rosenbergii post larvae.

\begin{tabular}{|c|c|c|c|c|c|c|c|c|c|c|c|c|}
\hline \multirow[t]{2}{*}{ Parameters } & \multicolumn{2}{|c|}{$35 \% \mathrm{CP}$} & \multicolumn{2}{|c|}{$40 \% \mathrm{CP}$} & \multirow[t]{2}{*}{ MSE \pm} & \multicolumn{2}{|c|}{$9: 12 \mathrm{~h}$} & \multicolumn{2}{|c|}{$9: 15 \mathrm{~h}$} & \multicolumn{2}{|c|}{$9: 18 \mathrm{~h}$} & \multirow[t]{2}{*}{ MSE \pm} \\
\hline & $\hat{0}$ & 우 & $\hat{0}$ & 오 & & क & 오 & o & 오 & $\hat{0}$ & 오 & \\
\hline Initial body weight, mg prawn-1 & 0.0208 & 0.0208 & 0.0208 & 0.0208 & 0.017 & 0.0208 & 0.0208 & 0.0208 & 0.0208 & 0.0208 & 0.0208 & 0.017 \\
\hline Final body weight, g prawn ${ }^{-1}$ & $8.62^{\mathrm{a}}$ & $5.89^{c}$ & $7.85^{\mathrm{b}}$ & $5.54^{c}$ & 1.65 & $8.48^{\mathrm{a}}$ & $5.67^{b}$ & $8.56^{a}$ & $5.80^{b}$ & $8.67^{\mathrm{a}}$ & $5.68^{b}$ & 1.88 \\
\hline Weight gain g 84 days $^{-1}$ prawn $^{-1}$ & $8.60^{\mathrm{a}}$ & $5.87^{b}$ & $7.83^{\mathrm{a}}$ & $5.52^{b}$ & 1.65 & $8.46^{\mathrm{a}}$ & $5.65^{b}$ & $8.54^{\mathrm{a}}$ & $5.78^{b}$ & $8.65^{\mathrm{a}}$ & $5.66^{b}$ & 1.85 \\
\hline Specific growth rate(\% day) & $7.18^{\mathrm{a}}$ & $6.72^{b}$ & $7.06^{\mathrm{a}}$ & $6.65^{b}$ & 0.001 & $7.16^{\mathrm{a}}$ & $6.68^{b}$ & $7.17^{\mathrm{a}}$ & $6.70^{b}$ & $7.18^{\mathrm{a}}$ & $6.68^{b}$ & 0.001 \\
\hline Feed conversion ratio & $2.10^{b}$ & $2.22^{b}$ & $2.43^{\mathrm{a}}$ & $2.73^{a}$ & 0.001 & $2.27^{b}$ & $2.70 \mathrm{ab}$ & $2.23 \mathrm{ab}$ & $2.75^{a}$ & $2.03^{c}$ & $2.35^{a b}$ & 0.69 \\
\hline Protein efficiency ratio & $1.37^{\mathrm{a}}$ & $1.36^{a}$ & $1.13^{b c}$ & $0.94^{c}$ & 0.21 & $1.27^{b}$ & $1.05^{c}$ & $1.30 \mathrm{ab}$ & $1.04^{c}$ & $1.42^{a}$ & $1.21^{b}$ & 0.11 \\
\hline
\end{tabular}

Means in the same row sharing the same superscript are not significantly different $(P \geq 0.05)$.

Table 4: Effect of different dietary protein level and feeding time irrespective of each other on chemical body composition of freshwater prawn Macrobrachium rosenbergii post larvae.

\begin{tabular}{|c|c|c|c|c|c|c|c|}
\hline Parameters & $35 \% \mathrm{CP}$ & $40 \% \mathrm{CP}$ & MSE \pm & $9: 12 \mathrm{~h}$ & $9: 15 \mathrm{~h}$ & $9: 18 \mathrm{~h}$ & MSE \pm \\
\hline Dry matter (\%) & 24.53 & 23.74 & 0.88 & 23.60 & 24.17 & 24.94 & 0.001 \\
\hline Crude protein (\%) & 55.53 & 56.43 & 0.65 & $50.51^{c}$ & $62.29^{a}$ & $55.14^{\mathrm{b}}$ & 1.06 \\
\hline Crude fat (\%) & $23.85^{\mathrm{a}}$ & $19.44^{b}$ & 1.45 & $24.03^{a}$ & $18.46^{c}$ & $22.44^{b}$ & 2.1 \\
\hline Ash (\%) & $20.62^{b}$ & $24.13^{\mathrm{a}}$ & 1.20 & $25.46^{a}$ & $19.25^{\mathrm{c}}$ & $22.42^{b}$ & 1.65 \\
\hline Gross energy, Kcal g ${ }^{-1}$ & $5.39^{a}$ & $5.03^{b}$ & 0.45 & 5.13 & 5.26 & 5.24 & 0.12 \\
\hline
\end{tabular}

Means in the same row sharing the same superscript are not significantly different $(P \geq 0.05)$.

Table 5: Effect of different dietary protein level and feeding time irrespective of each other on chemical body composition of male and female freshwater prawn Macrobrachium rosenbergii post larvae

\begin{tabular}{|c|c|c|c|c|c|c|c|c|c|c|c|c|}
\hline \multirow{2}{*}{ Parameters } & \multicolumn{2}{|c|}{$35 \%$ CP } & \multicolumn{2}{|c|}{$40 \%$ CP } & \multirow{2}{*}{ MSE \pm} & \multicolumn{2}{|c|}{$9: 12 \mathrm{~h}$} & \multicolumn{2}{|c|}{$9: 15 \mathrm{~h}$} & \multicolumn{2}{|c|}{$9: 18 \mathrm{~h}$} & \multirow[t]{2}{*}{ MSE \pm} \\
\hline & $\delta^{\pi}$ & q & $0^{\pi}$ & q & & 8 & 오 & $\delta^{\pi}$ & q & $\delta^{\pi}$ & q & \\
\hline Dry matter (\%) & $25.00^{a}$ & $24.40^{\mathrm{b}}$ & $24.09^{b}$ & $23.38^{\circ}$ & 0.99 & $23.23^{b}$ & $23.98^{b}$ & $23.95^{\mathrm{b}}$ & $24.39 \mathrm{ab}$ & $26.57^{\mathrm{ab}}$ & $23.31^{\mathrm{b}}$ & 1.22 \\
\hline Crude protein (\%) & $55.13^{b}$ & $55.93^{b}$ & $55.06^{\mathrm{b}}$ & $57.80^{\mathrm{a}}$ & 1.65 & $50.64^{d}$ & $50.39 \mathrm{e}$ & $63.17^{\mathrm{a}}$ & $61.41^{a b}$ & $51.48^{\mathrm{cd}}$ & $58.79^{b}$ & 1.88 \\
\hline Crude fat (\%) & $20.62^{b}$ & $27.07^{\mathrm{a}}$ & $18.55^{\mathrm{b}}$ & $20.33^{b}$ & 1.33 & $21.04^{b}$ & $27.03^{a}$ & $15.53^{\mathrm{c}}$ & $21.40^{\mathrm{b}}$ & $22.20^{\mathrm{b}}$ & $22.69^{\mathrm{b}}$ & 1.85 \\
\hline Ash (\%) & $24.25^{\mathrm{ab}}$ & $17.00^{\circ}$ & $26.39^{a}$ & $21.87^{\mathrm{b}}$ & 1.23 & $28.32^{\mathrm{a}}$ & $22.58^{\mathrm{b}}$ & $21.30^{b c}$ & $17.19^{d}$ & $26.32^{\text {ab }}$ & $18.52^{\text {cd }}$ & 2.14 \\
\hline Gross energy, Kcal g ${ }^{-1}$ & $5.06^{\mathrm{b}}$ & $5.72^{\mathrm{a}}$ & $4.86^{\circ}$ & $5.19^{\mathrm{b}}$ & 0.51 & $4.85^{\mathrm{c}}$ & $5.40^{\mathrm{ab}}$ & $5.04^{b}$ & $5.49^{\mathrm{a}}$ & $5.01^{\mathrm{b}}$ & $5.47^{\mathrm{a}}$ & 0.45 \\
\hline
\end{tabular}

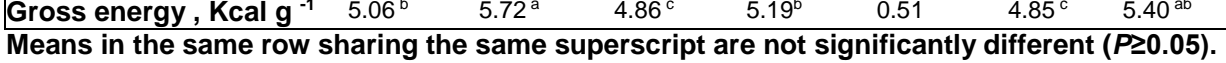


J. Agric. Sci. Mansoura Univ., 32 (6), June, 2007

4903 